Dent, C. E. (1948). Biochem. 9. 43, I69.

Elsden, S. R. \& Lewis, D. (1953). Biochem. F. 55, 183.

El-Shazly, K. (r952a). Biochem. F. 51, 640 .

El-Shazly, K. (1952b). Biochem. $\mathscr{f} . \mathbf{5 1}, 647$.

Friedemann, T. E. \& Graeser, J. B. (1933). \%. biol. Chem. 100, 29 1.

Gale, E. F. (I940). Bact. Rev. 4, I35.

Greenberg, L. A. \& Lester, D. (1944). F. biol. Chem. 154, I77.

James, A. T. \& Martin, A. J. P. (1952). Biochem. F. 50, 679.

Lewis, D. (1951). Biochem. F. 49, 149.

Lewis, D. (1954). Biochem. 7. 56, 39I.

McDonald, I. W. (1948). Biochem. F. 42, 584 .

McDonald, I. W. (1952). Biochem. F. 5I, 86.

Markham, R. (1942). Biochem. F. 36, 790 .

Nisman, B. (1954). Bact. Rev. 18, 16.

Partridge, S. M. \& Westall, R. G. (1948). Biochem. F. 42, 238.

Pearson, R. M. \& Smith, J. A. B. (1943). Biochem. F. 37, 153.

Peters, J. P. \& Van Slyke, D. D. (1932). Quantitative Clinical Chemistry. Vol. 2. Methods. Baltimore: Williams and Wilkins.

Sijpesteijn, A. K. \& Elsden, S. R. (1952). Biochem. F. 52, 41.

Sirotnak, F. M., Doetsch, R. N., Brown, R. E. \& Shaw, J. C. (1953). F. Dairy Sci. 36, I 17 .

\title{
An Investigation of the Daily Intakes of Food of Individual Boys at a Boarding School in Uganda
}

\author{
By RUTH SCHWARTZ AND R. F. A. DEAN \\ Medical Research Council Group for Research in Infantile Malnutrition, Mulago \\ Hospital, Kampala, Uganda \\ (Received 9 fanuary 1955)
}

The original purpose of the investigation was to measure the amount of food eaten by boys in the school, which was a boarding school, at a time when an unpopular diet had to be given because of high prices and shortages of better-liked foods. It was the best the school authorities could devise, but they had doubts of its value, and whether the boys were eating enough. The food eaten daily by thirty boys was therefore measured for I week. In the following term it proved possible to re-introduce betterliked foods, and the intakes of the thirty boys were measured again. The school food was not very ample so, to test its adequacy, nineteen of the boys were allowed to eat as much of it as they wanted for a further week during which their intakes were measured for the third time.

\section{EXPERIMENTAL}

\section{Background of the investigation}

Details of the school. The school is in the province of Buganda about 19 miles from Kampala. A large proportion of its pupils are children of chiefs or other prominent and prosperous members of the community; $85 \%$ are Baganda, an autochthonous Bantu tribe. The school fees are high by local standards but they defray only a fraction of the cost of the school; the rest is paid by a Uganda Government grant. 
The school is run on the lines of an English public school; the headmaster is a European, and the staff of the secondary school, where all subjects are taught in English, is partly European. There is a separate primary school with an all-African staff. Girls are admitted to both schools, but form only $17 \%$ of the secondary school and $33 \%$ of the primary school. The kitchen, which supplies the primary school as well, is adjacent to the secondary-school dining room.

Kitchen and feeding arrangements. Some years ago the building of a new kitchen was begun, but for lack of money has never been completed. The partly finished walls, covered with a corrugated metal roof, shelter the cooking range, a series of low brick walls enclosing spaces in which wood is burnt. The spaces are covered with iron slabs with holes for the cooking pots, which are of iron and of two sizes, holding either 18 or 24 gal. The water for cooking is obtained from a single tap outside the kitchen and is heated in two large pots permanently sunk into brick stoves. In some of the unroofed rooms of the unfinished kitchen, and in an outhouse, vegetables are cleaned, and nuts are pounded with heavy wooden pestles in narrow wooden vessels.

A small amount of food is stored in two sheds which are kept locked; one of them serves also as an office for the caterer. The sheds are the only parts of the kitchen quarters that are well protected from the weather. On rainy days the firewood is usually wet, and meals are often late in consequence.

For many years an African caterer has bought the food and he supervises its cooking and distribution. Most of it has to be bought in Kampala where it is dearer than in the country but, except for some vegetables, it is impossible to buy food locally in sufficient quantities. Storage of food is limited by lack of accommodation and by the poor keeping qualities of the staple foods in a tropical climate.

The cooking and distribution of food. In Buganda, as in many other parts of Africa, a meal nearly always consists of a boiled or steamed, starchy staple accompanied by a sauce made of nuts and beans, meat, fish, or a mixture of vegetables. The two main meals served in the school each day were of that type; at the third meal, breakfast, porridge made with dried skim milk was served with tea containing milk and sugar (see Table $x$ ).

The cooking of the food was very simple. Plantains and sweet potatoes were tied up in cloths and steamed in the large pots on a bed of banana leaves. The vegetables for the sauces were fried in small amounts of fat and added to the main ingredients which had previously been boiled soft in water. The maize-meal porridge was made with water, and the sugar and dried milk were added towards the end of cooking. The food for the two main meals was always cooked in the largest pots, and was stirred with heavy wooden sticks. The head cook served out the food into smaller aluminium pots which were taken into the dinning rooms. There was nearly always more food per head in the secondary school dining room than in the two other dining rooms, and serving pots for the secondary school were usually filled a second time.

The school food. As far as possible the school had always attempted to supply the kind of food habitually eaten by the Baganda. The green plantain (Musa balbisiana) locally known as matoke, is the most popular staple. When that is not available, sweet 
potatoes, lumonde (Ipomoea batatas), or rice may be eaten, and wheat-flour bread is becoming increasingly well liked. But rice and bread are expensive and the poorer people often have to fall back on cassava and maize flour. There is, however, very little knowledge of how to cook maize. It is usual to make the flour with water into a tasteless stiff porridge called posho, which is eaten widely in Kenya and in some parts of Uganda, but is despised by the Baganda, and there were always violent objections when it appeared in the school diet; a posho made with wheat was, however, more acceptable. Maize meal, made into a thinner, sweet porridge with dried milk and plenty of sugar, was normally well accepted in the school, though it was unpopular at times, which was hardly a cause for wonder, because most of the maize meal sold in Kampala is coarsely ground and is often bitter and musty. Recently, it has been possible to obtain a finer meal, made from well-dried grain, properly kept.

Matoke (green plantain) is uneconomical and comparatively expensive at any time, and from 50 to $60 \%$ of the bulk is lost in preparation; nevertheless, it was served as often as possible. The alternative, lumonde (sweet potato), is equally wasteful, but far cheaper. Rice was served occasionally. At the time of the investigation the money allotted for catering was I East African shilling (containing 100 cents and equivalent to I English shilling) for each boy daily. Out of that sum the wages of the twelve cooks had to be paid, so that only 9 I cents were available for food. In the two first terms of I953 meat, which was the most expensive item, was served only twice a week but, in spite of that, the food allowance was much overspent owing to a sudden and unusual increase in food prices after poor crops caused by a prolonged drought. The difficulties were acute, and the school's domestic science mistress was asked to re-plan the diet for the third term of 1953 so as to ensure the maximum food value without further overexpenditure. Supplies of green plantains had become unreliable as well as expensive so they were cut out altogether and sweet potatoes were only served occasionally as an addition to a main meal. Instead of the usual staples a steamed wheat-flour cake, made from standard flour of about $85 \%$ extraction, was offered with sauce at the evening meals and maize meal formed the basis of the midday meals. In the next term, after a satisfactory rainy season, it became possible to revert to a more popular diet but, because of the expense, some of the skim milk was omitted, and the amount of animal protein was unfortunately reduced still further because the boys refused to eat tinned meat which was offered instead of the usual fresh meat. Details of the two diets are given in Tables $I$ and 2.

The values in Table I, which shows details of the food allotted by the school, are calculated as $\frac{1}{400}$ th of an average of the quantities cooked daily, 400 being approximately the total number of children, boys and girls together, in the school. They are somewhat less than the amounts laid down by the domestic science mistress because, in an attempt to be as economical as possible, the caterer had reduced the amounts since food was almost always left in the secondary-school dining room.

In the course of the investigation a large difference was revealed between the amount of food in theory supplied by the school and that eaten by the boys (see Table 6). About one-third of the total calories intended for the boys apparently did 


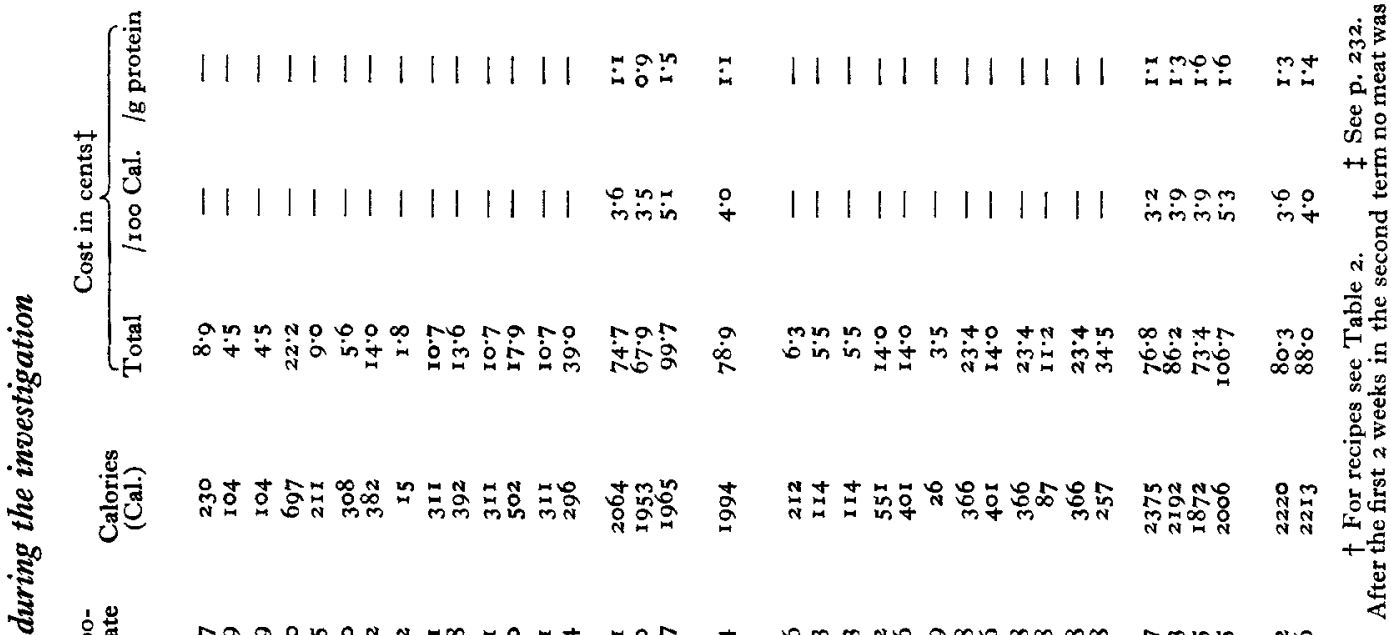

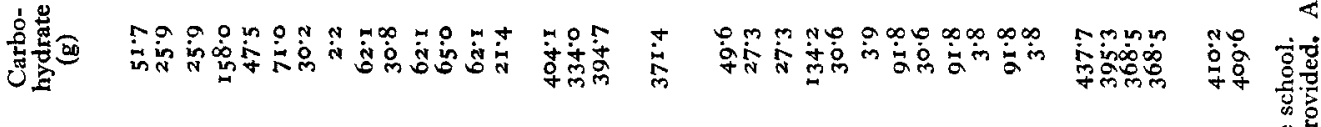

ज

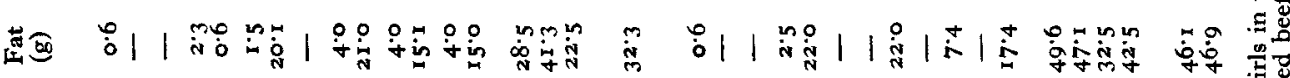

(2)

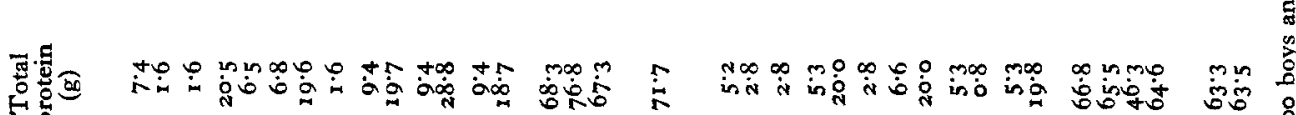

$\overbrace{}^{\circ}$

.

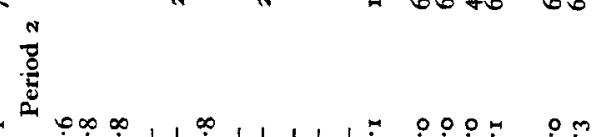

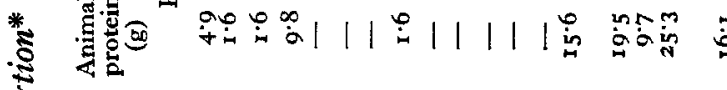

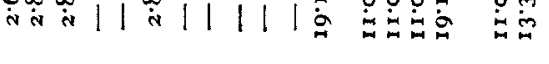

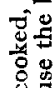

ธั

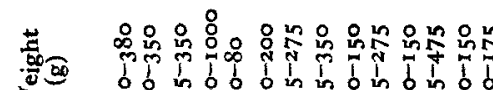

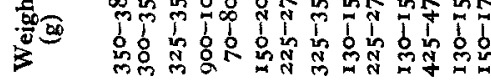

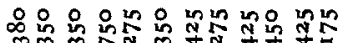

:

胥

รี

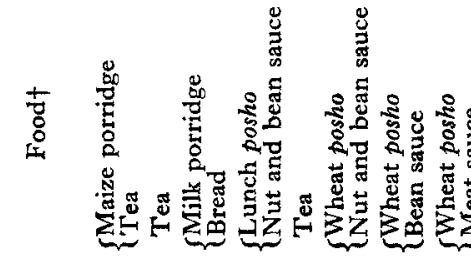

bind

竎等

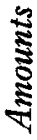

$\dot{4}$

尊

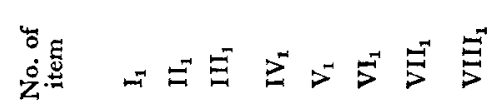

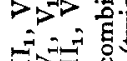

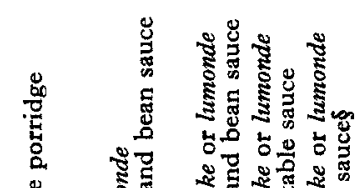

要

(3)

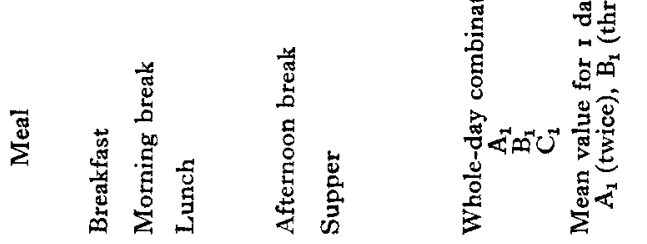

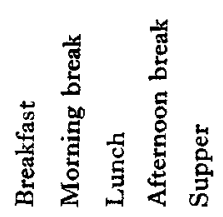


not reach them; the school food was being shared, officially or unofficially, by many other people, including the cooks and kitchen staff, and the servants of Europeans working at the school.

Table 2. Recipes used at the school (quantities taken for 400 portions)

\begin{tabular}{|c|c|c|c|c|c|c|c|}
\hline & & $\begin{array}{r}\text { Wei } \\
\text { as co }\end{array}$ & $\begin{array}{l}\text { ight } \\
\text { oked }\end{array}$ & & & $\begin{array}{l}\text { Wei } \\
\text { as co }\end{array}$ & $\begin{array}{l}\text { oked } \\
\text { oked }\end{array}$ \\
\hline Item & Ingredients & $\begin{array}{l}\text { Period I } \\
\quad(\mathrm{kg})\end{array}$ & $\begin{array}{l}\text { Period } 2 \\
\quad(\mathrm{~kg})\end{array}$ & Item & Ingredients & $\begin{array}{l}\text { Period I } \\
\quad(\mathrm{kg})\end{array}$ & $\begin{array}{l}\text { Period } 2 \\
\text { (kg) }\end{array}$ \\
\hline $\begin{array}{l}\text { Breakfast } \\
\text { porridge }\end{array}$ & $\begin{array}{l}\text { White maize flour } \\
\text { Yellow maize flour } \\
\text { Sugar } \\
\text { Skim milk powder }\end{array}$ & $\begin{array}{l}\text { II.34 } \\
- \\
9 \cdot 07 \\
5 \cdot 67\end{array}$ & $\begin{array}{r}- \\
\text { I 1.34 } \\
9 \cdot 07 \\
3 \cdot 06\end{array}$ & $\begin{array}{l}\text { Bean } \\
\text { sauce }\end{array}$ & $\begin{array}{l}\text { Beans (dried) } \\
\text { Standard wheat flour } \\
\text { Fat } \\
\text { Salt }\end{array}$ & $\begin{array}{r}45 \cdot 35 \\
5 \cdot 67 \\
5 \cdot 67 \\
\mathbf{r} \cdot 81\end{array}$ & $\begin{array}{l}- \\
-\end{array}$ \\
\hline $\begin{array}{l}\text { Breakfast } \\
\text { and break }\end{array}$ & $\begin{array}{l}\text { Tea dust } \\
\text { Sugar }\end{array}$ & $\begin{array}{l}0.46 \\
9.07\end{array}$ & $\begin{array}{l}0.46 \\
9.77\end{array}$ & & $\begin{array}{l}\text { Onions } \\
\text { Vegetables (as available) }\end{array}$ & $\begin{array}{l}5 \cdot 44 \\
5 \cdot 89\end{array}$ & - \\
\hline tea & Skim milk powder & $I \cdot 8 I$ & 3.40 & Meat & Fresh meat & $32 \cdot 65$ & - \\
\hline $\begin{array}{l}\text { Afternoon } \\
\text { tea }\end{array}$ & $\begin{array}{l}\text { Tea dust } \\
\text { Skim milk powder }\end{array}$ & $\begin{array}{l}0.46 \\
I \cdot 8 r\end{array}$ & $\begin{array}{l}0.46 \\
3.40\end{array}$ & sauce & $\begin{array}{l}\text { White maize flour } \\
\text { Standard wheat flour }\end{array}$ & $\frac{10 \cdot 20}{5.67}$ & $\begin{array}{l}- \\
3 \cdot 28 \\
3 \cdot 17\end{array}$ \\
\hline $\begin{array}{l}\text { Lunch } \\
\text { porridge }\end{array}$ & $\begin{array}{l}\text { White maize flour } \\
\text { Sugar } \\
\text { Skim milk powder }\end{array}$ & $\begin{array}{l}45 \cdot 35 \\
22 \cdot 67 \\
\text { II } \cdot 34\end{array}$ & - & & $\begin{array}{l}\text { Sait } \\
\text { Onions } \\
\text { Vegetables (mixed) }\end{array}$ & $\begin{array}{l}3 \cdot 87 \\
5 \cdot 44 \\
5 \cdot 89\end{array}$ & $\begin{array}{r}1 \cdot 81 \\
12 \cdot 35 \\
12 \cdot 35\end{array}$ \\
\hline $\begin{array}{l}\text { Lunch } \\
\text { posho }\end{array}$ & $\begin{array}{l}\text { White maize flour } \\
\text { Lumonde }\end{array}$ & $\begin{array}{l}22 \cdot 67 \\
45 \cdot 35\end{array}$ & - & Steamed & $\begin{array}{l}\text { Curry powder } \\
\text { Standard wheat flour }\end{array}$ & - & $\begin{array}{r}0.23 \\
-\end{array}$ \\
\hline $\begin{array}{l}\text { Nut and } \\
\text { bean } \\
\text { sauce }\end{array}$ & $\begin{array}{l}\text { Groundnuts } \\
\text { Beans (dried) } \\
\text { Fat } \\
\text { Salt } \\
\text { Onions } \\
\text { Tomatoes } \\
\text { Cabbage }\end{array}$ & $\begin{array}{r}11 \cdot 34 \\
22 \cdot 67 \\
2 \cdot 83 \\
1 \cdot 81 \\
5 \cdot 69 \\
6 \cdot 80 \\
-\end{array}$ & $\begin{array}{r}12 \cdot 10 \\
22 \cdot 80 \\
3.06 \\
1 \cdot 81 \\
5 \cdot 69 \\
-6.30\end{array}$ & $\begin{array}{l}\text { wheat } \\
\text { cake }\end{array}$ & $\begin{array}{l}\text { Baking powder } \\
\text { Fat } \\
\text { Salt }\end{array}$ & $\begin{array}{l}0.91 \\
0.91 \\
0.28\end{array}$ & - \\
\hline
\end{tabular}

Extra food. The school has a tuck shop at which sugar; sweets and bread can be bought, and local vendors come to the school on most days with buns, sweets, nuts and fruit; fruit was, however, more usually picked from trees in the grounds of the school or from the private gardens of the European staff. Some items were brought or sent from home. The items constituting the extras are shown in Table 3 .

\section{Technique of the investigation}

The boys who took part in the investigation were all volunteers aged from 9 to 20 years; twenty-four were in the primary school and eight in the secondary school. Younger children were not included as being unlikely to co-operate sufficiently. There was no other selection. The boys investigated were almost exactly one-tenth of the total number of boys in the school and appeared to represent a good random sample; their weights are shown in Fig. I against the curve of weight for age for all the $3 \circ 3$ boys in the school. There was stormy political feeling in the secondary school which made it not possible to include as many boys above the age of $\mathrm{r}_{4}$ years as was desirable.

Intake was measured for 7 consecutive days, and not more than eight boys were investigated at any one time. Two European members of the Medical Research Council Group for Research in Infantile Malnutrition stayed at the school during the 
Table 3. Contribution of different items to total calories from extras

\begin{tabular}{|c|c|c|c|c|c|c|}
\hline \multirow[b]{2}{*}{ Item } & \multicolumn{2}{|c|}{ Period I } & \multicolumn{2}{|c|}{ Period 2} & \multicolumn{2}{|c|}{ Period 3} \\
\hline & $\begin{array}{l}\text { No. of } \\
\text { boys }\end{array}$ & $\begin{array}{l}\text { Proportion of } \\
\text { total extra } \\
\text { calories } \\
(\%)\end{array}$ & $\begin{array}{c}\text { No. of } \\
\text { boys }\end{array}$ & $\begin{array}{l}\text { Proportion of } \\
\text { total extra } \\
\text { calories } \\
(\%)\end{array}$ & $\begin{array}{c}\text { No. of } \\
\text { boys }\end{array}$ & $\begin{array}{l}\text { Proportion of } \\
\text { total extra } \\
\text { calories } \\
(\%)\end{array}$ \\
\hline Sugar & 30 & 43 & 32 & 53 & 20 & 66 \\
\hline Bread & 24 & 24 & 24 & $2 I$ & 16 & IO \\
\hline Buns & 16 & 10 & 22 & I3 & 10 & 6 \\
\hline Nuts & 20 & 9 & 7 & 2 & - & - \\
\hline Biscuits & 6 & $<I$ & I I & 2 & 5 & 3 \\
\hline Plain cake & 5 & $<\mathrm{I}$ & I & $<I$ & - & - \\
\hline Butter & 4 & $<\mathbf{I}$ & 5 & $<I$ & 2 & $<\mathbf{I}$ \\
\hline Jam & 5 & $<$ I & 4 & $<\mathrm{I}$ & $I$ & $<\mathrm{I}$ \\
\hline Boiled egg & - & - & I & $<I$ & - & - \\
\hline Curry powder & 一 & - & I & $<I$ & - & - \\
\hline Condensed milk & 2 & $<\mathrm{I}$ & - & - & - & - \\
\hline Grasshoppers & 2 & $<\mathbf{I}$ & - & - & - & - \\
\hline Boiled beans & 7 & $<\mathrm{I}$ & - & - & - & 一 \\
\hline Boiled maize & 2 & $<\mathbf{I}$ & - & - & 2 & $<\mathrm{I}$ \\
\hline Boiled rice & 2 & $<\mathrm{r}$ & - & - & I & $<\mathrm{I}$ \\
\hline Millet porridge & I & $<\mathrm{I}$ & - & - & - & - \\
\hline Fruit squash & 2 & $<\mathbf{I}$ & 3 & $<\mathbf{I}$ & $\mathbf{I}$ & $<\mathrm{I}$ \\
\hline Avocado pears & - & - & 7 & 2 & 2 & $<\mathrm{I}$ \\
\hline Bananas & 3 & $<$ I & 2 & $<\mathrm{I}$ & 3 & 2 \\
\hline Grenadilloes & 3 & $<\mathbf{I}$ & - & - & - & 一 \\
\hline Lemons & 4 & $<\mathrm{I}$ & - & - & - & - \\
\hline Mangoes & 4 & $<\mathrm{I}$ & I & $<\mathrm{I}$ & - & - \\
\hline Oranges & 8 & $<\mathrm{I}$ & $\mathbf{I}$ & $<\mathrm{I}$ & 2 & $<I$ \\
\hline Pawpaw & $\mathbf{I}$ & $<\mathrm{I}$ & - & - & - & - \\
\hline Pineapple & $\mathbf{I}$ & $<\mathrm{I}$ & - & - & - & - \\
\hline Boiled sweets & 19 & 3 & $\mathbf{5}$ & I & 10 & 3 \\
\hline Toffees & 2 & $<\mathrm{I}$ & - & 一 & - & - \\
\hline
\end{tabular}

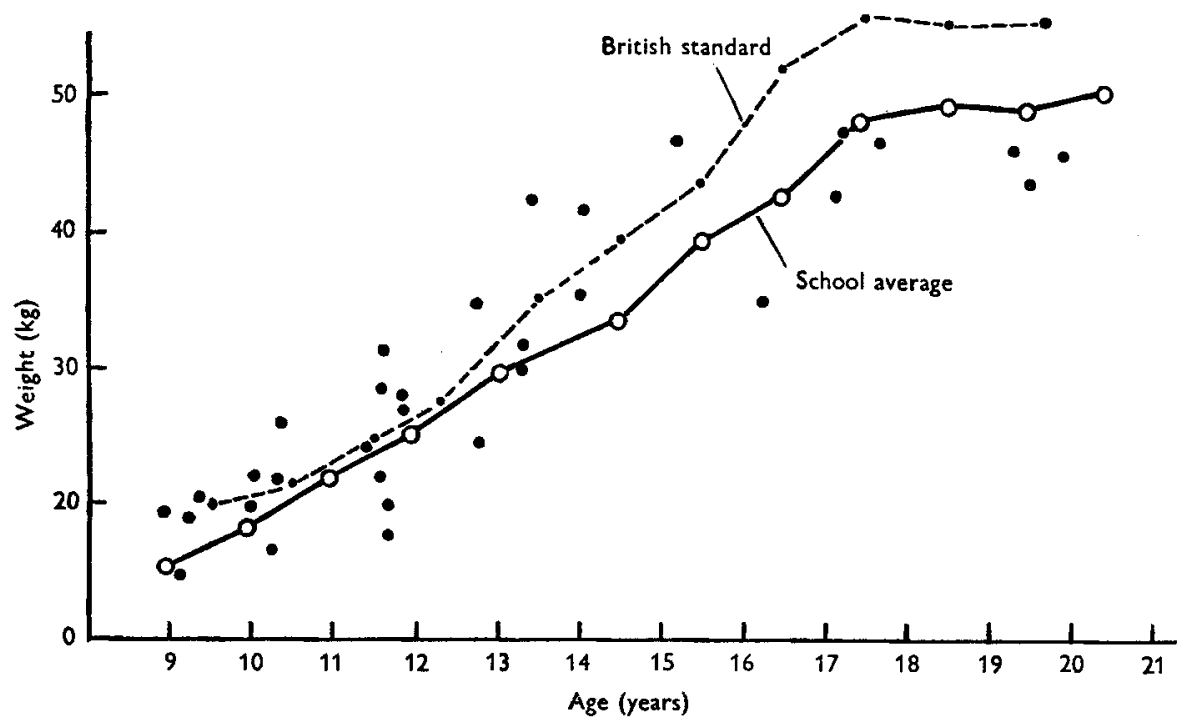

Fig. I. Mean weights at the beginning of period I (shown as dots) of the thirty-two boys taking part in the investigation compared with the mean for all the boys in the school and with a British standard (Widdowson, 1947). 
investigation. They were present at all the meals and weighed the food served out to each boy, and any food that might be left over, on a spring balance weighing up to I kg. Each boy had his own numbered plate and cup which he kept during his investigation period. Most of the extra items bought by the boys were weighed at meal times, especially in the two tea breaks; food eaten in the dormitories was weighed by a house prefect who was provided with a balance.

Records were made each day of the amounts of food put into the cooking pots. Weighed samples of the cooked food were dried on flat tins in the sun to obtain an estimate of the water content, which varied considerably from day to day. Sun drying was the most practical method as there was no electricity or gas at the school. The food values were calculated from tables of food composition (Platt, 1945; McCance \& Widdowson, 1946; Chatfield, 1953), the factors $4 \cdot 1,9.3$ and 3.75 being used for the calorie value of protein, fat and carbohydrate, respectively. It was recognized that the method of calculation might involve many errors, especially because the values used had been determined for foods grown elsewhere than in Uganda, but facilities for chemical analysis were not available at the time. For this reason no attempt was made to calculate the intake of minerals and vitamins.

In the period when the food intake was unrestricted, one of the observers served the boys of the investigation group out of separate pots which always contained an excess of food. It was unfortunate that because of the political situation mentioned earlier, no older boys could be included in this third investigation.

There were no data from African sources that could be used to provide standards of weight for age, or of calorie intake for age. For the purpose of comparison with the present results, the data collected by Widdowson (1947) on British children in 1937-9 have been used.

In the following account, the time when the unpopular diet was measured is referred to as period I, and the other times when the more popular diet was given, first in the habitual way and afterwards in unlimited amount, as periods 2 and 3 .

\section{RESULTS}

Total intakes. The mean daily intakes in the three periods are shown in Table 4. The amounts of animal protein, total protein, fat and carbohydrate, and the calorie values, are given with comparable figures from Widdowson (1947). In the children investigated by Widdowson, there was a well-marked change of intake with age, but in the African schoolchildren no such change could be demonstrated either in the intake of calories from all sources (Fig. 2) or in the intake from school food only (Fig. 3). The means obtained by combining the results for children of different ages are, therefore, valid whereas similar means from Widdowson's figures would have little significance.

The amount of carbohydrate eaten by the African boys was at least as great as the amount eaten by the British boys. The total protein was slightly lower than the figures for the British boys 9 years old, and the animal protein and fat were very much lower. The mean calorie intakes were therefore lower; the younger children took daily about $700 \mathrm{Cal}$, and the older children about 1500 Cal., less than the British boys. 
When the change was made from the unpopular to the popular diet (periods I and 2), there was an increase in the intake from school food and a decrease from extras, but there was no increase in the total calorie intake; the small difference between the mean values of 1953 and 1889 Cal. was not statistically significant. The mean amounts of

Table 4. Mean total daily intakes by the schoolboys in periods $\mathrm{I}-3$

\begin{tabular}{|c|c|c|c|c|c|c|c|c|c|c|c|}
\hline \multirow[b]{2}{*}{ Period } & \multirow[b]{2}{*}{$\begin{array}{l}\text { No. of } \\
\text { boys }\end{array}$} & \multicolumn{2}{|c|}{$\underbrace{\text { Animal protein }}_{(\mathrm{g})}$} & \multicolumn{2}{|c|}{$\begin{array}{c}\text { Total protein } \\
(\mathrm{g})\end{array}$} & \multicolumn{2}{|r|}{$\underbrace{\text { Fat }}(\mathrm{g})$} & \multicolumn{2}{|c|}{$\overbrace{(\mathrm{g})}^{\begin{array}{c}\text { Carbohydrate } \\
\text { (n) }\end{array}}$} & \multicolumn{2}{|c|}{$\begin{array}{l}\text { Calories } \\
\text { (Cal.) }\end{array}$} \\
\hline & & Mean & $\underbrace{}_{\text {Range }}$ & Mean & Range & Mean & Range & Mean & Range & Mean & Range \\
\hline I & 30 & 15.5 & $8 \cdot 6-23 \cdot 4$ & $59 \cdot 9$ & $40 \cdot 7-76 \cdot 9$ & $26 \cdot 8$ & $12 \cdot 5-45^{\circ} 9$ & $389 \cdot 5$ & $286 \cdot 0-504 \cdot 4$ & I953 & $1459-2345$ \\
\hline 2 & $32 \dagger$ & $8 \cdot 7^{*}$ & $6 \cdot 8-I I \cdot I$ & $45 \cdot 5^{*}$ & $33 \cdot 4-57 \cdot 5$ & $28 \cdot 0$ & $21 \cdot 5-36 \cdot 3$ & $383 \cdot 7$ & $323 \cdot 9-488 \cdot 0$ & 1889 & $1619-2377$ \\
\hline 3 & I9t & $I O \cdot I$ & $7 \cdot 1-12 \cdot 8$ & $55^{\cdot 6 *}$ & $41 \cdot 9-66 \cdot 6$ & $36 \cdot 3 *$ & $24 \cdot I-53 \cdot 2$ & $401 \cdot 9$ & $332 \cdot 3-498 \cdot 6$ & 2073 & I $748-2528$ \\
\hline \multicolumn{12}{|c|}{ British children: } \\
\hline \multirow{2}{*}{\multicolumn{2}{|c|}{$\begin{array}{l}9 \text { years old } \\
\text { I } 8 \text { years old }\end{array}$}} & 43 & & 68 & & 97 & & 308 & & 2443 & \\
\hline & & 60 & & 97 & & 137 & & 402 & & 3427 & \\
\hline
\end{tabular}

(Widdowson, 1947)

* These values are significantly different $(P<0.05)$, by statistical analysis, from the figures immediately above them in the same column.

$\uparrow$ Two extra boys, in addition to the original thirty, volunteered to have their diets measured in period 2. They did not affect the general means.

$\mp$ The mean intakes in period 2 of the nineteen children investigated in period 3 were in all respects the same as the general means in period 2.

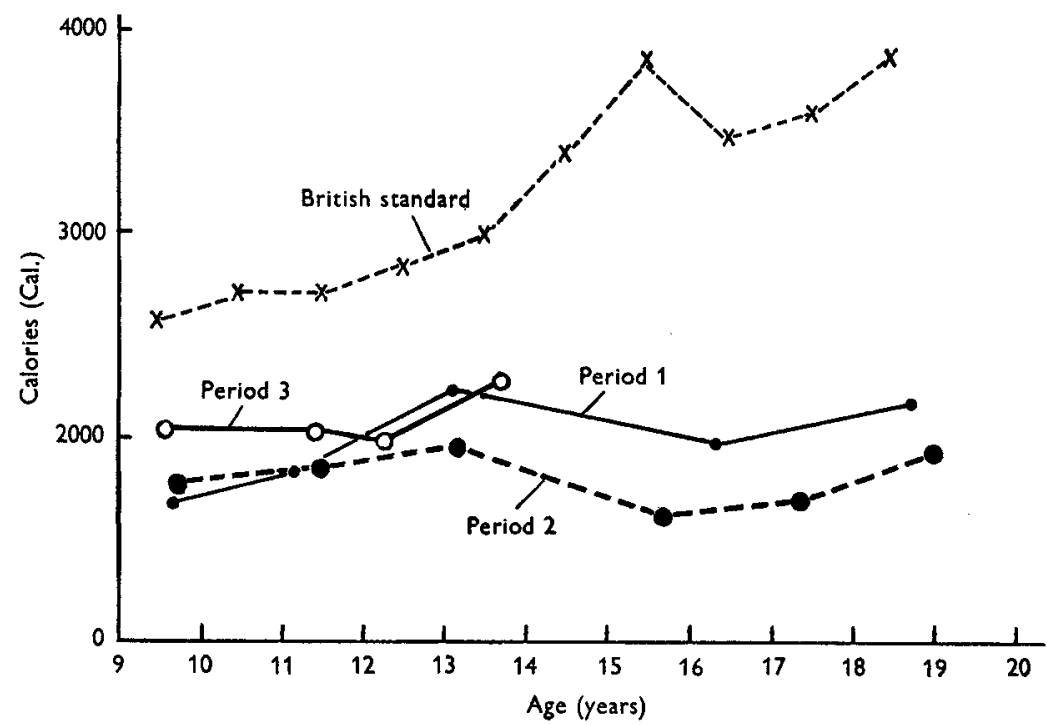

Fig. 2. Mean daily total caloric intakes in the three periods of the investigation, compared with intakes of British children of the same age (Widdowson, r947).

total protein and animal protein fell, but the mean amounts of fat and carbohydrate did not alter. The fall in protein was only in part caused by the change of staple foods; as already explained (p. 232) there were other changes that affected the amount of animal protein. 
When the popular diet was offered in unlimited quantities (period 3), the mean total calorie intake increased by 184 Cal. There was a mean increase of $275 \mathrm{Cal}$. due to school food, and extras decreased by $9 \mathrm{I} \mathrm{Cal}$. The $275 \mathrm{Cal}$. were accounted for by mean increases of $\mathrm{I} .3 \mathrm{~g}$ total protein, IO. $\mathrm{g}$ fat and $35.6 \mathrm{~g}$ carbohydrate. These figures show that the increase could not have been chiefly due to the eating of larger amounts of the staples, which contained very little protein and fat. Analyses showed, in fact, that the item of food of which the consumption increased most was sauce, which increased $27 \%$ by weight; matoke, lumonde and breakfast porridge increased by much less, only $12 \%$. Tea increased by $7 \%$.

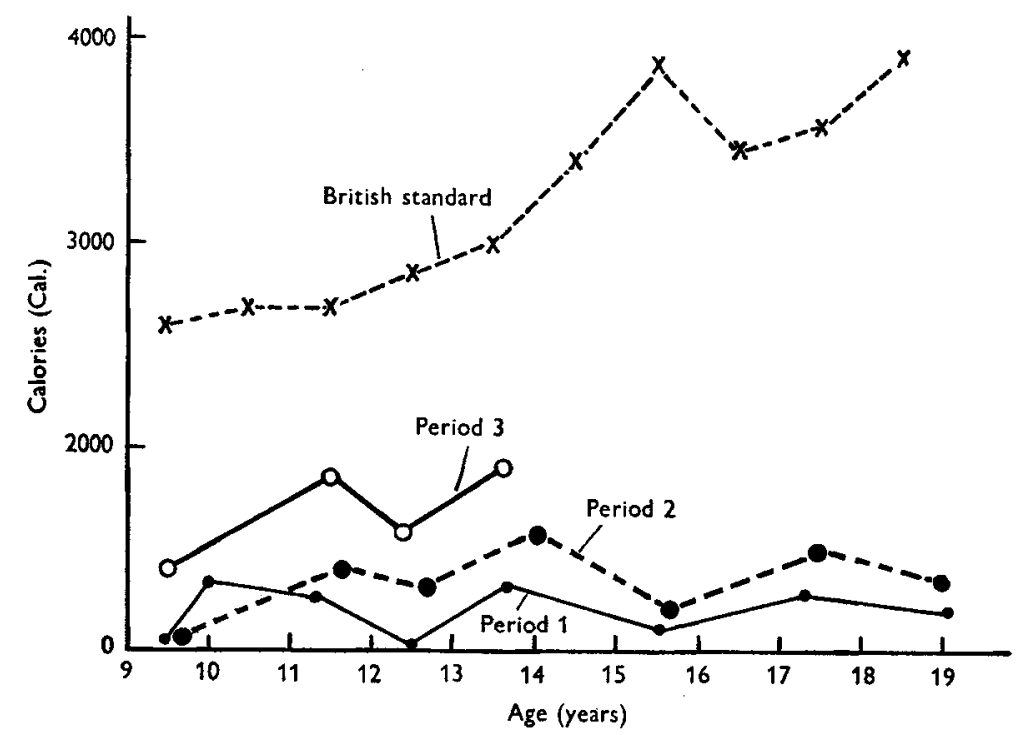

Fig. 3. Mean daily caloric intakes derived from school food in the three periods of the investigation, compared with intakes of British children of the same age (Widdowson, 1947).

Proportions of protein, fat and carbohydrate. Table 5 shows the percentages of the total calories that were derived from protein, fat and carbohydrate, and comparable British values. In the school diets, the contributions of animal protein and fat were very small. The percentage contribution of total protein was greatest in the unpopular diet of period I, and then slightly exceeded the British percentage; it was a little lower

Table 5. Proportion of total calories derived by the schoolboys from protein, fat and carbohydrate in periods $\mathbf{I}-3$

\begin{tabular}{|c|c|c|c|c|}
\hline \multirow[b]{2}{*}{ Period } & \multicolumn{4}{|c|}{ Proportion of total calories derived from } \\
\hline & $\begin{array}{c}\text { Animal } \\
\text { protein } \\
(\%)\end{array}$ & $\begin{array}{c}\text { Total } \\
\text { protein } \\
(\%)\end{array}$ & $\begin{array}{l}\text { Fat } \\
(\%)\end{array}$ & $\begin{array}{c}\text { Carbohydrate } \\
(\%)\end{array}$ \\
\hline $\mathbf{I}$ & 3.3 & $\mathrm{I} 2 \cdot 5$ & $12 \cdot 7$ & $74 \cdot 8$ \\
\hline 2 & $1 \cdot 9$ & $9 \cdot 9$ & 13.7 & $76 \cdot 3$ \\
\hline 3 & $2 \cdot 0$ & II.O & $16 \cdot 2$ & $72 \cdot 8$ \\
\hline \multicolumn{5}{|c|}{ British-boys (Widdowson, 1947) } \\
\hline & $7 \cdot 5$ & II 99 & $36 \cdot 4$ & $5 \mathrm{I} \cdot 3$ \\
\hline
\end{tabular}


in the other periods. Carbohydrate, which was responsible for only half of the British boys' calories, was responsible for three-quarters of the African total in all three periods.

Intake from school food and from extras. The average intakes from school food are shown in Table 6. They were, as already mentioned (p. 232), much lower than the amounts theoretically allocated by the school authorities. The calories obtained from the school diet were supplemented by the extras bought by the boys; as shown in the lower part of the table, 569 Cal. were obtained from extras in period $I$, and $4 \mathrm{I} 5$ and 324 in periods 2 and 3 , respectively. The extras were obviously an important part of the diet (see Table 7).

Table 6. Mean daily amounts of school food allocated by the school authorities, amounts actually eaten, and amounts of extras

\begin{tabular}{|c|c|c|c|c|c|c|c|c|c|c|c|c|}
\hline \multirow{2}{*}{$\begin{array}{l}\text { Class } \\
\text { of food }\end{array}$} & \multirow[b]{2}{*}{ Period } & \multirow{2}{*}{$\begin{array}{l}\text { No. of } \\
\text { boys }\end{array}$} & \multicolumn{2}{|c|}{$\begin{array}{l}\text { Animal protein } \\
(\mathrm{g})\end{array}$} & \multicolumn{2}{|c|}{$\begin{array}{l}\text { Total protein } \\
\text { (g) }\end{array}$} & \multicolumn{2}{|r|}{$\begin{array}{l}\text { Fat } \\
\text { (g) }\end{array}$} & \multicolumn{2}{|c|}{$\begin{array}{l}\text { Carbohydrate } \\
\text { (g) }\end{array}$} & \multicolumn{2}{|r|}{$\begin{array}{l}\text { Calories } \\
\text { (Cal.) }\end{array}$} \\
\hline & & & Mean & Range & Mean & Range & Mean & Range & Mean & Range & Mean & Range \\
\hline $\begin{array}{l}\text { Amount } \\
\text { allocated } 2 \\
\text { by school }\end{array}$ & 2 and 3 & - & $\begin{array}{l}19 \cdot 8 \\
13 \cdot 3\end{array}$ & $\overrightarrow{-}$ & $\begin{array}{l}74 \cdot 4 \\
62 \cdot 4\end{array}$ & - & $\begin{array}{l}32 \cdot 5 \\
46 \cdot 9\end{array}$ & - & $\begin{array}{l}391 \cdot 7 \\
406 \cdot 2\end{array}$ & - & $\begin{array}{l}2082 \\
2213\end{array}$ & - \\
\hline $\begin{array}{l}\text { Intake from } \\
\text { school food }\end{array}$ & $\begin{array}{ll}n & \text { I } \\
\text { d } & 2 \\
& 3\end{array}$ & $\begin{array}{l}30 \\
32 \\
19\end{array}$ & $\begin{array}{r}15 \cdot 2 \\
8 \cdot 7 \\
10 \cdot 1\end{array}$ & $\begin{array}{l}8 \cdot 6-25 \cdot 9 \\
6 \cdot 0-11 \cdot 1 \\
7 \cdot 1-12 \cdot 8\end{array}$ & $\begin{array}{l}49 \cdot 5 \\
40 \cdot 9 \\
52 \cdot 2\end{array}$ & $\begin{array}{l}35 \cdot 4-69 \cdot 7 \\
28 \cdot 5-50 \cdot 3 \\
34 \cdot 2-64 \cdot 3\end{array}$ & $\begin{array}{l}19 \cdot 4 \\
24 \cdot 1 \\
34 \cdot 2\end{array}$ & $\begin{array}{r}9 \cdot 4-37 \cdot 9 \\
13 \cdot 0-34 \cdot 4 \\
28 \cdot 6-42 \cdot 3\end{array}$ & $\begin{array}{l}267 \cdot 5 \\
288 \cdot 8 \\
324 \cdot 4\end{array}$ & $\begin{array}{l}160 \cdot 9-372 \cdot 4 \\
172 \cdot 3-344 \cdot 1 \\
247 \cdot 5-388 \cdot 4\end{array}$ & $\begin{array}{l}1384 \\
1474 \\
\text { I749 }\end{array}$ & $\begin{array}{r}975-1735 \\
1000-1874 \\
1275-2235\end{array}$ \\
\hline $\begin{array}{l}\text { Intake } \\
\text { from } \\
\text { extras }\end{array}$ & $\begin{array}{l}\text { I } \\
2 \\
3\end{array}$ & $\begin{array}{l}30 \\
32 \\
19\end{array}$ & $\frac{0.3}{-}$ & $\begin{array}{c}0.0-0.3 \\
-\end{array}$ & $\begin{array}{r}10 \cdot 4 \\
4.6 \\
3.4\end{array}$ & $\begin{array}{l}0.2-19.5 \\
0.0-11.2 \\
0.4-7.7\end{array}$ & $\begin{array}{l}7 \cdot 4 \\
3 \cdot 9 \\
2 \cdot 1\end{array}$ & $\begin{array}{l}0.2-12.5 \\
0.2-8 \cdot 2 \\
0.1-6.9\end{array}$ & $\begin{array}{r}\text { I22.0 } \\
94 \cdot 9 \\
77 \cdot 5\end{array}$ & $\begin{array}{l}31 \cdot 1-220 \cdot 7 \\
14 \cdot 3-163 \cdot 5 \\
34 \cdot 8-138 \cdot 6\end{array}$ & $\begin{array}{l}5^{69} \\
4^{1} 5 \\
3^{2} 4\end{array}$ & $\begin{array}{l}148-1192 \\
169-718 \\
173-613\end{array}$ \\
\hline
\end{tabular}

As might be expected, the contribution of extras was greatest in period $\mathrm{r}$, when the school diet was so unpopular. In that period, and also in periods 2 and 3 , the chief extra was sugar, and the amount taken did not change much from period to period. One-third, one-fourth and one-fifth of the carbohydrates in periods 1,2 and 3 , respectively, were extras, and sugar was mainly responsible. Every child was expected to provide his own sugar for the afternoon tea, which was served unsweetened, but most of the boys brought sugar to every other meal at which tea was served; it was quite common to add from 30 to $5 \circ \mathrm{g}$ sugar to a cup that already contained $20 \mathrm{~g}$, and frequently sugar was sprinkled on the sweet breakfast porridge. There appeared to be no limit to the acceptable degree of sweetness. The mean amount of extra sugar eaten in a week was about $420 \mathrm{~g}$, but one child had $1300 \mathrm{~g}$ and another, a small boy at the end of term, had only $20 \mathrm{~g}$ in the week.

In period I the consumption of sustaining foods, such as bread, buns and nuts, was greater than in the other periods, and in the secondary school the much disliked wheat cake was replaced occasionally with boiled rice or millet porridge, when a cook could be persuaded to prepare them. The variety of extras also was greatest in period I; it was least in period 3 , partly because that period was near the end of term, when most of the term's pocket money had been spent. The amounts of money spent on extras during the investigation varied from I4 East African cents (the equivalent of about $1 \frac{3}{4} d$.) to 5.35 East African shillings (about $5 s .4 d$.) in a week, and could not be related 
to the age of the child, or to any other factor. Details of the extras, including the calorie contribution of each item, are given in Table 3 .

Intake in relation to body-weight. Widdowson (1947) found that individual variation was so great that it was impossible to predict the calorie intake of an individual child from its age, weight, height or surface area. The number of children in the present investigation was so small that means for the intakes of yearly age groups could have little meaning; the ranges (see Table 4) were, however, much less than those reported by Widdowson, who found that at all ages the maximum was about twice the minimum.

Table 7. Proportion of total intakes of the schoolboys supplied by extras

\begin{tabular}{|c|c|c|c|c|c|c|}
\hline Period & $\begin{array}{l}\text { No. of } \\
\text { boys }\end{array}$ & $\begin{array}{c}\text { Animal } \\
\text { protein } \\
(\%)\end{array}$ & $\begin{array}{c}\text { Total } \\
\text { protein } \\
(\%)\end{array}$ & $\begin{array}{l}\text { Fat } \\
(\%)\end{array}$ & $\begin{array}{c}\text { Carbohydrate } \\
(\%)\end{array}$ & $\begin{array}{c}\text { Calories } \\
(\%)\end{array}$ \\
\hline $\mathrm{I}$ & 30 & 2 & I7 & 28 & $3 \mathrm{I}$ & 29 \\
\hline 2 & 32 & $\circ$ & I0 & 14 & 25 & 22 \\
\hline 3 & 19 & 0 & 6 & 6 & 19 & 16 \\
\hline
\end{tabular}

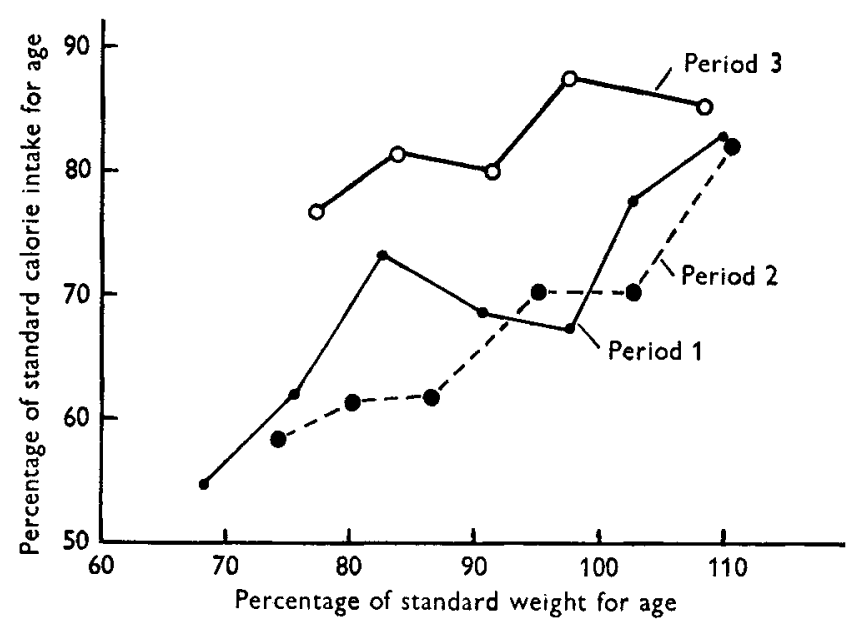

Fig. 4. Mean percentage of standard weight for age for the boys in the three periods of investigation plotted against mean percentage of standard caloric intake for age. The standards are those of Widdowson (1947) for British children.

The narrowness of the range in the African children is puzzling; it cannot be accounted for entirely by the failure of the school to provide an item of diet that could be used for filling-up, or by any restrictions in the amount of extras, and it seemed that very large appetites either did not occur, or could not be satisfied. The former alternative must seem strange to anyone with experience of European children, but it may not be so strange in a community in which the staple foods are always bulky in relation to their calorie value.

In one respect the African children showed a fair degree of consistency. If they were divided according to their degree of approach to the British standard for weight, those who were nearest to that standard also had calorie intakes that were nearest to the intakes of British children (Fig. 4). In other words, the children who were well 
grown for their age had the best appetites or at least got the most food. The conclusion may seem reasonable, but it was not necessarily self-evident. The calorie intakes of children who were small for their age, under $90 \%$ of the weight of British children of the same age, were examined separately from those of the children who were large for their age, in each of the three trial periods. In period 2 most of the children who were small for their age had a lower calorie intake than they had in period $\mathbf{I}$, and most of the children who were large for their age had about the same intake as in period $\mathrm{I}$. The differences in the mean intakes of the two groups in both periods were found to be significant when analysed statistically. In period 3 the largest children did not have greater average intakes than the smallest, and did not increase their intakes more.

\section{DISCUSSION}

One of the most remarkable features of the investigation was the discovery of the low calorie intakes of the children. It was originally thought that the main factor limiting intake in period $\mathrm{I}$ was the unpopularity of the food offered by the school. The intakes in period 2, when the food was more popular, were much lower than was expected, the consumption of school food being only slightly greater than in period I. In both periods food was hardly ever left over, at least in the dining room of the primary school, and it might be argued that the limiting factor in period 2 was the small amount of food that was offered. But even in period 3, where there was no limit to the food available, all the intakes were still below $90 \%$ of those of British boys of the same ages; for some reason the boys failed to eat enough of the popular diet to provide them with a large calorie intake. It must be remembered, however, that the boys investigated in period 3 were all under 15 years of age; older and larger boys might have achieved greater intakes.

There were no clinical signs of undernutrition in the children who took part in the investigation or in any other children at the school, which has been under more or less constant supervision for over 3 years. The general weight curve of boys at the school is known; it is shown in Fig. I, and is clearly below that of British children. The curve for Africans cannot with certainty be taken as evidence of a state of malnutrition; it may merely correspond to a pattern of growth slower than that of British children, a suggestion that is reinforced by some other work (as yet unpublished) that has shown a tendency for African children to grow in height for some years after British children have stopped.

The weights of the children investigated were fairly representative, in relation to age, of weights in general at the school (Fig. I); especially at the lower ages, they tended to be above the mean rather than below it. The children's weights do not prove that their nutritional status was good but, if it was bad, the failure of their calorie intake to increase greatly when they were offered unlimited amounts of the food they liked best, was all the more remarkable; undernourished children can be expected to have large appetites, except in the few specific diseases of malnutrition in which anorexia is a feature.

The important question seems to be whether the children investigated suffered from 
the consequences of a deficient diet. The school diet in periods 2 and 3 resembled fairly closely that eaten in most Baganda homes, but it has been established, by routine weighings, that the children usually gain more weight at home in their holidays than they do during term time. A similar phenomenon has been observed in children at English public schools (Widdowson \& McCance, 1944), and is probably explained, especially in the African children, by the greater amount of activity that is enforced at school. In the wealthiest homes, better food may add to the effects of inactivity. The difference between the diets of the moderately well-off and the rich seems to reside, not in the quantities of plantains and sweet potatoes that are eaten, but in the quantity and quality of the sauces. The school diet was low in fat. It is known that when the Baganda can afford to do so, they eat considerably more fat than was given to the children, and eat it mostly in their sauces. If the sauces are very rich, African children may achieve calorie intakes near those of British children. The chief reason for the small calorie intakes may have been the limitation enforced by the bulkiness of the diet, and it would have been interesting to offer a supplement of fat that would yield more calories without increasing the size of the helpings. It is possible that a larger calorie intake would stimulate faster growth, but that could be settled only by a carefully controlled experiment in which food of the best quality attainable, within the limits of taste and capacity, was given for a period of 2 years or more. The experiment would be valuable; at present very little is known for certain about the growth potentialities of Africans. It is popularly believed that their growth is limited by inadequate feeding, but as yet there is little evidence for that belief.

There is no agreement about ideal rates of growth, and ideal final stature, but it seems that if the results of the present investigation are widely applicable, the young child must possess an enormous appetite, and be so fortunate as to obtain the finest sauces, if he is to grow to the maximum of his capabilities. On the other hand, the lower calorie intake that seems to be his more usual lot may, for all that can be said with certainty at the moment, be entirely adequate. Comparisons with British children may be misleading. The needs of European and African children may differ in many ways. The higher African temperature may reduce the necessary calorie intake by more than $5 \%$ (Food and Agriculture Organization of the United Nations: Committee on Calorie Requirements, I950), although the validity of making such a correction for children might be questioned, and there are undoubtedly many other unknown factors that should be taken into consideration.

The protein intakes of the African children were low compared with those of British children. The total intake of protein on the unlimited diet of period 3 was under $60 \mathrm{~g}$ daily, and the animal protein in period $\mathrm{I}$, in which it was highest, was only $15 \mathrm{~g}$ daily. It is known, however, that adults may be physically active when living on diets containing less than $60 \mathrm{~g}$ total protein, and that their blood chemistry is entirely normal (Mirone, 1954), and there is no known necessity for a high proportion of animal protein in a diet that has enough total protein. The proportion of the total calories derived from protein in the diets of the African children was almost exactly the same as that in those of the British children investigated by Widdowson (1947).

It is impossible to say whether the addition of protein to the African diet would be 
an advantage, and that is another matter for speculation until it has been settled by the long overdue experiment. Nothing is known about the absorption and utilization of protein in these children.

One other feature that seems worthy of comment was the children's consumption of sugar. The amount of sugar taken as an extra, and therefore eaten uncooked, has already been mentioned; a further $300 \mathrm{~g}$ was supplied by the school, making a weekly total of $720 \mathrm{~g}$. British children aged about 9-II years took as much (Widdowson, 1947), but only about $25^{\circ} \mathrm{g}$ of it actually as sugar, in tea, or sprinkled on breakfast cereals, puddings and stewed fruit; the African children took about $520 \mathrm{~g}$ of their sugar uncooked, chiefly in tea. It would be of interest to find out whether uncooked sugar taken in this way is deleterious to the teeth. At one time the school had provided sugar-cane but it was one of the earliest casualties of the drive for economy.

Finally, it is necessary to consider to what extent the nutrition of the school described is representative of that in schools in Uganda. No statistical data are available, but information obtained from various sources makes it obvious that the school is one of the better fed. There is no evidence that the children at any of the schools are undernourished, and it must be emphasized that until it has been shown definitely, in controlled feeding trials, that dietary supplements are advantageous, any scheme for increasing or improving the diet will be without scientific foundation or justification.

\section{SUMMARY}

I. Individual food intakes of boys from 9 to 20 years old, chiefly Baganda, were measured at a boarding school in Uganda, for three periods, (I) when the school diet was unpopular and limited in amount (thirty boys), (2) when the school diet was popular but still limited (thirty-two boys), and (3) when the popular school diet was offered in an unlimited amount (nineteen boys).

2. All the food intakes were below $90 \%$ of those of British boys of the same ages, even when unlimited school food was offered. The intakes bore no relation to age, but wellgrown children at any age had better appetites than those that were less well grown.

3. The intake did not increase when unlimited school food was offered, possibly because the bulkiness of the diet made larger amounts unacceptable.

4. All the boys supplemented the school food with extras which accounted for one-third, one-fourth and one-fifth of the total intakes in periods ${ }_{1-3}$, respectively. The most important extra item was sugar which was taken chiefly in tea in large quantities.

5. Although some of the boys were underweight by British standards, no definite signs of undernutrition were seen.

6. The implications of the findings are discussed in relation to the customary diet of the boys, and it is stressed that the supplementation of African diets, however justifiable it may be in theory, needs first the foundation of exact experiment.

We wish to thank Miss M. G. Robinson and Miss R. Hecht for their valuable help in collecting the information. They also, with $\mathrm{Mr} \mathrm{P}$. P. M. Jones, made many of the calculations. The work would not have been possible without the friendly co-operation 
of the Headmaster of the school, and we are most grateful to him. He and others of his staff very kindly provided accommodation for the members of the Medical Research Council Group who lived at the school during the investigation. The Domestic Science Mistress and the Caterer were at all times willing to give information about the school food, and to help in many other ways. Finally, we wish to thank most warmly the boys who took part in the investigation, although it caused considerable disruption of their routine.

\title{
REFERENCES
}

Chatfield, C. (1953). F.A.O. nutr. Stud. no. 3 .

Food and Agriculture Organization of the United Nations: Committee on Calorie Requirements (x950). F.A.O. nutr. Stud. no. 5 .

McCance, R. A. \& Widdowson, E. M. (1946). Spec. Rep. Ser. med. Res. Coun., Lond., no. 235, and ed. Mirone, L. (1954). Amer. F. clin. Nutr. 2, 246.

Platt, B. S. (1945). Spec. Rep. Ser. med. Res. Coun., Lond., no. 253.

Widdowson, E. M. (1947). Spec. Rep. Ser. med. Res. Coun., Lond., no. 257.

Widdowson, E. M. \& McCance, R. A. (1944). Lancet, 247, 152.

\section{Metabolism of Carotene and Vitamin A Given by Mouth or Vein in Oily Solution or Aqueous Dispersion to Calves, Rabbits and Rats}

\author{
By S. K. KON, W. A. McGILLIVRAY* AND S. Y. THOMPSON \\ National Institute for Research in Dairying, University of Reading
}

(Received I 7 fanuary I955)

It is now generally accepted that in many species of the higher animals carotene taken by mouth is converted to vitamin $A$ in the intestinal wall (see, for example, review by Kon \& Thompson, I95I). There is both less agreement and less evidence on the value as vitamin A precursor of carotene given parenterally (cf. Church, MacVicar, Bieri, Baker \& Pope, I954). The observations of Tomarelli, Charney \& Bernhart ( 1946 ) about the relation between the utilization of carotene introduced by injection and its state of dispersion offer an explanation of the divergence of findings. The careful work of Bieri \& Sandman (I95I) and Bieri \& Pollard (I954) with rats, of Hentges, Grummer \& Sorensen (1952) with pigs, of Church et al. (1954) with sheep, and of Bieri (I955) with chicks and rabbits, shows beyond reasonable doubt that these animals under suitable conditions convert into vitamin A carotene introduced directly into the body. In all these experiments carotene was dispersed in water-miscible surface-active agents. With the same technique Eaton, Matterson, Decker, Helmboldt \& Jungherr (195I) found conversion in the calf, but Church et al. (1954) failed to do so.

* On leave of absence from the Massey Agricultural College, Palmerston North, New Zealand. 